\title{
Cetirizine Hydrochloride
}

National Cancer Institute

\section{Source}

National Cancer Institute. Cetirizine Hydrochloride. NCI Thesaurus. Code C28920.

A synthetic phenylmethyl-piperazinyl derivative, antihistaminic Cetirizine is a metabolite of hydroxyzine and a selective peripheral histamine $\mathrm{H} 1$-receptor antagonist. It is used for symptomatic treatment of seasonal and perennial allergic rhinitis and for chronic urticaria. ( $\mathrm{NCl04)}$ 